\title{
STUDI EKSPLORATIF PERSEPSI GURU TERHADAP KEBIJAKAN BELAJAR DARI RUMAH PADA MASA PANDEMI COVID-19
}

\author{
Marzoan \\ marzoanswandy@gmail.com \\ STKIP Hamzar Lombok Utara
}

\begin{abstract}
This study aims to obtain teacher perceptions about the impact of the implementation of the Learning from Home policy according to a circular from the Minister of Education and Culture dated March 24, 2020, which regulates the implementation of education during the coronavirus spread. The research method uses exploratory case studies, the research approach uses qualitative case study methods which are used to obtain information about the effectiveness of the learning process from home during the Covid-19 pandemic. This research was conducted in June 2020. Respondents of this study were 20 elementary school teachers spread across five districts in North Lombok Regency, West Nusa Tenggara. Respondents were drawn from each elementary school teacher spread over five districts. The data of this study were sourced from the results of questionnaire and interview answers developed based on a review of relevant literature. All respondents filled out a research questionnaire online through the Google forms application, then the questionnaire was confirmed via telephone interview. The results of this study conclude that learning policies from home during the Covid-19 pandemic period according to teacher perceptions have not been implemented well and according to teacher observations, only $25 \%$ of students actually carry out learning from home. As many as $60 \%$ of teachers feel that their burden becomes heavier when compared to the learning process that has been carried out in classi fication or face-to-face and 65\% of teachers state that they need additional skills to be able to carry out the learning process from home.
\end{abstract}

Keywords: teacher perception, learning from home, Covid-19 pandemic

\section{ABSTRAK}

Penelitian ini bertujuan untuk mendapatkan persepsi guru mengenai dampak dari implementasi kebijakan Belajar dari Rumah sesuai surat edaran dari Menteri Pendidikan dan Kebudayaan tanggal 24 Maret 2020 yang mengatur pelaksanaan pendidikan pada masa darurat penyebaran coronavirus. Metode penelitian menggunakan studi kasus eksplorasi, pendekatan penelitiannya menggunakan metode studi kasus kualitatif yang digunakan untuk mendapatkan informasi mengenai efektivitas proses belajar dari rumah selama masa pandemic Covid-19. Penelitian ini dilaksanakan pada bulan Juni 2020. Responden penelitian ini adalah 20 orang guru sekolah dasar yang tersebar di lima kecamatan di Kabupaten Lombok Utara Nusa Tenggara Barat. Responden diambil dari masingmasing guru sekolah dasar yang tersebar di lima kecamatan. Data penelitian ini bersumber dari hasil jawaban kuesioner dan wawancara yang dikembangkan berdasarkan kajian literatur yang relevan. Seluruh responden mengisi kuesioner penelitian secara online melalui aplikasi google forms, lalu kuesioner dikonfirmasi melalui wawancara via telepon. Hasil penelitian ini menyimpulkan bahwa kebijakan belajar dari rumah selama masa pandemic Covid-19 menurut persepsi guru belum terlaksana dengan baik dan menurut pengamatan guru, hanya $25 \%$ siswa saja yang benar-benar melaksanakan belajar dari rumah. Sebanyak $60 \%$ guru merasa bahwa beban mereka menjadi lebih berat bila dibandingkan dengan proses belajar yang selama ini dilakukan secara klasikan maupun 
tatap muka dan $65 \%$ guru menyatakan bahwa mereka membutuhkan keterampilan tambahan untuk dapat melaksanakan proses belajar dari rumah.

Kata kunci : persepsi guru, belajar dari rumah, pandemi Covid-19 


\section{PENDAHULUAN}

Berbicara pendidikan adalah berbicara tentang masa depan suatu bangsa. Pendidikan menjadi kunci karena memiliki peranan yang sangat penting terhadap terwujudnya peradaban bangsa. Inilah mengapa pendidikan harus senantiasa mendapat perhatian khusus, baik dalam situasi normal maupun dalam situasi darurat agar keberlangsungan dan masa depan suatu bangsa dapat terjamin. Bila aspek pendidikan diabaikan pada masa darurat, maka dikhawatirkan akan menyebabkan ancaman serius terhadap eksistensi suatu bangsa. Sejarah telah mencatat bahwa bangsa-bangsa di dunia yang serius memperhatikan kualitas pendidikannya terbukti menjadi negera-negera yang lebih mudah bangkit dan bergerak menjadi negara maju.

Setelah Badan Kesehatan Dunia (WHO) pada 11 Maret 2020 mengumumkan bahwa virus corona sebagai pendemi global. Maka sejak saat itu, hampir semua negara di seluruh belahan dunia menyatakan mengalami masa darurat kesehatan. Pandemi ini berdampak pada berbagai sektor kehidupan, tidak terkecuali bidang pendidikan. Tidak hanya terjadi dimana awal mula virus ini berkembang, tapi di hampir semua negara termasuk Indonesia. Kondisi inilah yang sedang dihadapi oleh bangsa Indonesia sekarang, yaitu ancaman penyebaran virus Corona yang berpotensi mengancam sektor pendidikan.

COVID-19 merupakan penyakit yang baru ditemukan oleh karena itu pengetahuan terkait pencegahannya masih terbatas. Kunci pencegahan meliputi pemutusan rantai penularan dengan isolasi, deteksi dini, dan melakukan proteksi dasar (Susilo, 2020). Dalam berbagai sumber disebutkan bahwa Virus Corona Disease 2019 (COVID-19) merupakan penyakit infeksi saluran pernapasan yang disebabkan oleh severe acute respiratory syndrome virus corona 2 (SARS$\mathrm{CoV}-2$ ), atau yang sering disebut virus Corona. Virus ini memiliki tingkat mutasi yang tinggi dan merupakan patogen zoonotik yang dapat menetap pada manusia dan binatang dengan presentasi klinis yang sangat beragam, mulai dari asimptomatik, gejala ringan sampai berat, bahkan sampai kematian. Hal yang paling dikahatarikan dari virus ini adalah tingkat penularannya yang sangat tinggi dan menular antar manusia. Karena alasan itulah kemudian, tempat-tempat yang memungkinkan berkumpulnya banyak orang, seperti pusat perbelanjaan, tempat ibadah, sekolah dan lainlain menjadi perhatian pemerintah untuk melalukan tindakan cepat dalam rangka pencegahan penularan virus ini.

Seperti dilakukan oleh banyak negara, untuk mencegah penularan virus corona di sekolah, Menteri Pendidikan dan Kebudayaan menerbitkan surat edaran bertanggal 24 Maret 2020 yang mengatur pelaksanaan pendidikan pada masa darurat penyebaran virus corona. Kebijakan menutup sekolah terpaksa diambil untuk mencegah rsiko penyebaran virus Corona. Kebijakan serupa juga dilakukan oleh negera-negara lain yang terdampak Covid-19. Walaupun diawal pandemi merebak, beberapa negara masih berupaya untuk membuka sekolah seperti biasa. Namun, pada akhirnya karena pandemi yang kian mengganas, langkah penutupan sekolah mau tidak mau harus dilakukan untuk menyelamatkan sektor pendidikan.

Penerapan kebijakan belajar dari rumah dengan penutupan sementara aktivitas belajar di sekolah yang diputuskan dalam waktu yang mendadak dan tanpa persiapan yang cukup oleh guru dan pihak sekolah, tentu akan memiliki dampak terhadap proses pembelajaran. Dari berbagai studi yang 
dilakukan oleh beberapa pihak, baik oleh lembaga pemerintah maupun dari organisasi swasta nonprofit lainnya, menunjukkan bahwa kebijakan belajar dari rumah mendapat tanggapan yang bergam dari pihak sekolah, orang tua dan siswa.

Beragamnya persepsi guru dan masih terkesan gagapnya pihak sekolah dalam menerapkan proses belajar dari rumah mengindikasikan bahwa kebijakan yang diputuskan pemerintah masih mendapat beberapa tantangan di lapangan (sekolah). Guru sebagai ujung tombak implementasi kebijakan belajar dari rumah diindikasikan memiliki tindakan yang beragam terkait teknis dan tata cara pembelajaran yang efektif di masa pandemi. Beragamnya persepsi guru dipengaruhi oleh banyak factor. Oleh karena itu, penting mengetahui bagaiamana persepsi guru mengenai implementasi kebijakan belajar dari rumah sejak awal kebijakan ini diberlakukan hingga penelitian ini dilakukan.

Persepsi merupakan kemampuan untuk membeda-bedakan, mengelompokkan dan memfokuskan perhatiannya pada suatu obyek, yang selanjutnya diinterpretasi. Persepsi berlangsung pada saat seseorang menerima stimulus dari dunia luar yang ditangkap oleh organ-organ bantunya yang kemudian masuk ke dalam otak (Sarwono, 2009). Persepsi dalam konteks penelitian ini dimaksudkan pada interpretasi dan pemahaman guru setelah melalui proses berpikir mengenai kebijakan belajar dari rumah. Dengan mengetahui persepsi guru sejak awal, maka diharapkan akan mempermudah mendiagnosis kebutuhan belajar siswa di sekolah yang pada akhirnya berujung pada berbagai pilihan alternatif solusi strategi pembelajaran yang dapat dipilih oleh guru untuk proses belajar yang efektif bagi seluruh peserta didik, sehingga kualitas proses pembelajaran tetap dapat dipertahankan walaupun di masa darurat wabah pandemi Covid-19. Atas dasar itulah kemudian, penelitian dengan topik Studi Eksploratif Persepsi Guru terhadap Kebijakan Belajar dari Rumah pada Masa Pandemi Covid-19 ini dilakukan.

\section{METODE PENELITIAN}

Metode yang digunakan dalam penelitian ini adalah dengan studi kasus eksplorasi dan dengan pendekatan kualitatif. Morissan (2017) menyebutkan bahwa penelitian eksploratif adalah penelitian awal yang bertujuan untuk mendapatkan gambaran mengenai suatu topik penelitian yang akan diteliti lebih jauh. Secara konseptual, metode ini relevan digunakan untuk mendapatkan data terkait dampak dari kebijakan belajar dari rumah selama masa pandemic COVID-19 bagi anak, guru maupun bagi orang tua di rumah. Pemilihan sampel menggunakan metode purposive sampling. Sampel penelitian ini adalah guru SD di masing-masing kecamatan di Kabupaten Lombok Utara. Keseluruhan jumlah sampel dalam penelitian ini adalah 20 orang dengan rincian, Kecamatan Pemenang 4 orang, Kecamatan Tanjung 4 orang, Kecamatan Gangga 4 orang, Kecamatan Kayangan 3 orang dan Kecamatan Bayan 5 orang. Penelitian ini melibatkan 11 orang guru perempuan dan 9 orang guru laki-laki. Sampel penelitian ini relative kecil, namun diasumsikan dapat memenuhi kriteria dalam mengambil simpulan penelitian karena ukuran sampel didasarkan pada pencapaian kedalaman dan kekayaan deskripsi, bukan ukuran sampel. Sebagaimana yang disebutkan Guetterman (2015), bahwa ukuran sampel bukan masalah opini representative dan pandangan, tetapi lebih merupakan masalah kekayaan informasi.

Data primer dalam penelitian ini dikumpulkan melalui angket yang di isi secara online oleh 
responden menggunakan aplikasi google forms. Adapun untuk mendapatkan informasi yang lebih mendalam, dilakukan dengan menggunakan teknik wawancara melalui sambungan telepon, sedangkan data sekunder lainnya dikumpulkan dari berbagai sumber yang relevan, seperti hasil publikasi jurnal, berita media masa dan lain-lain. Angket penelitian ini mencakup beberapa hal, yaitu : 1) persepsi guru, 2) bagaimana proses belajar dari rumah, dan 3) dampak positif dan negatif kebijakan belajar dari rumah bagi guru dan siswa.

\section{HASIL PENELITIAN}

Merujuk hasil analisa data dapat diketahui bahwa semua guru sudah mengetahui informasai terkait kebijakan pemerintah mengenai Belajar dari Rumah (BDR) untuk menanggulangi penyebaran Covid-19, melalui surat edaran yang dikeluarkan pemerintah pusat maupun dari pemerintah daerah. Kebijakan ini oleh sebagian besar guru dianggap sangat mendadak dan langsung memberikan efek kejut yang besar bagi dunia pendidikan di daerah, sehingga tidak hanya guru dan praktisi pendidikan, kalangan masyarakat umum juga dengan cepat mengetahui adanya kebijakan pemerintah tentang proses belajar dari rumah. Sehingga dapat dipastikan bahwa semua sekolah di Kabupaten Lombok Utara menerapkan kebijakan belajar dari rumah sejak awal Maret 2020. Dari hasil jawaban angket dan wawancara dengan responden dapat diketahui bahwa persepsi guru terhadap kebijakan BDR dapat diuraikan sebagai berikut :

\section{Proses Belajar dari Rumah}

Terkait realisasi implementasi proses belajar dari rumah, persiapan yang dilakukan guru diantaranya adalah $75 \%$ guru telah mengirimkan surat pemberitahuan resmi dari sekolah mengenai pelaksanaan belajar dari rumah. Sebanyak $70 \%$ guru juga menginformasikan kepada orang tua mengenai peran orang tua dalam mendukung proses belajar dari rumah. Adapun media pembelajaran yang paling sering digunakan guru untuk mendukung proses belajar dari rumah adalah dengan bantuan media belajar offline seperti buku, LKS dan arahan tugas di rumah melalui pesan singkat SMS, selebihnya atau hanya $10 \%$ guru yang menggunakan media belajar online yang membutuhkan jaringan internet. Rendahnya prosentase penggunaan media pembelajaran berbasis online menurut guru lebih disebabkan oleh kondisi orang tua yang tidak memiliki gawai yang terkoneksi jaringan internet dan kondisi serta kemampuan orang tua yang beragam, sehingga diasumsikan akan kurang maksimal bila siswa sekolah dasar belajar secara online.

\section{Persepsi Guru}

Mengenai imlpelementasi proses belajar dari rumah, sebanyak $65 \%$ guru menyatakan bahwa proses belajar dari rumah belum terlaksana dengan baik, dan menurut pengamatan guru, hanya $25 \%$ siswa saja yang benar-benar melaksanakan belajar dari rumah. Proses belajar dari rumah juga menjadi beban baru bagi sebagian guru, karena sebanyak 60\% guru merasa bahwa beban mereka menjadi lebih berat bila dibandingkan dengan proses belajar yang selama ini dilakukan secara klasikan maupun tatap muka.

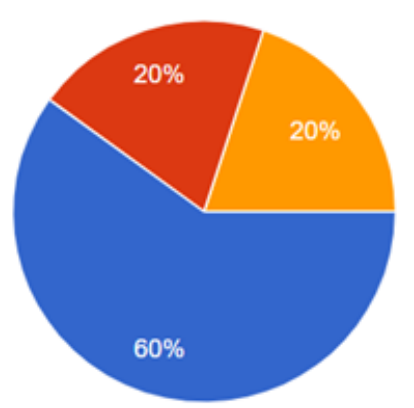


Setiap kebijakan baru, apalagi kebijakan

Beban menjadi lebih berat

Beban sama saja

Beban menjadi lebih ringan

Gambar 1 : Grafik Persepsi Guru Mengenai

Proses Belajar dari Rumah

Sebanyak $65 \%$ guru menyatakan bahwa mereka membutuhkan keterampilan tambahan untuk dapat melaksanakan proses belajar dari rumah. Diantara keterampilan tambahan yang dimaksud menurut jawaban guru diantaranya adalah (1) Mempersiapkan bahan atau materi pembelajaran tambahan yang relevan dengan informasi upaya pencegahan penyebaran Covid-19, (2) Keterampilan menyiapkan modul maupun media pembelajaran lain yang dapat efektif untuk menunjang proses belajar anak di rumah, (3) Keterampilan dalam menggunakan aplikasi pembelajaran berbasis online, (4) Strategi pembelajaran bagi siswa yang berada di wilayah zona merah yang tidak dapat dihubungi karena tidak memiliki gawai yang terkoneksi dengan jaringan internet, (5) Meningkatkan keterampilan dalam memaksimalkan bentuk pembelajaran dengan pemberian tugas melalui program tayangan televisi oleh pemerintah, (6) Keterampilan dalam memadukan materi pembelajaran dengan bermain sambil belajar di rumah, (7) Keterampilan membuat modul mandiri yang sederhana dan dapat diintegrasikan dengan LKS siswa, (8) Keterampilan dalam membuat animasi pembelajaran sesuai situasi wabah corona, dan (9) Keterampilan dalam menyesuaikan tugas tambahan yang diberikan kepada anak agar tidak jenuh selama belajar dari rumah.

\section{Dampak Positif dan Negatif BDR}

tersebut diambil di masa darurat tentu akan memiliki dampak, baik dampak positif maupun negatif. Berikut ini adalah tanggapan guru terhadap kemungkinan dampak positif proses belajar dari rumah, yaitu: $55 \%$ guru merasa berhasil mendorong keterlibatan orang tua dalam proses belajar siswa, $100 \%$ guru menjadi paham tentang manfaat teknologi dalam pendidikan, $75 \%$ guru menjadi lebih kreatif memberikan tugas ke siswanya, $85 \%$ guru memiliki kesempatan untuk menyeimbangkan antara beban pekerjaan di sekolah dan tugas rumah tangga. Gambaran dampak positif proses belajar dari rumah menurut guru disajikan dalam Grafik 2 berikut ini.

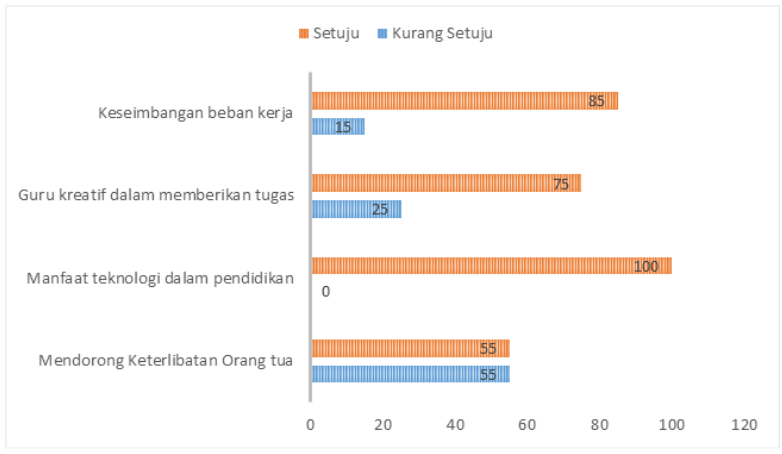

Gambar 2. Grafik Persepsi Guru terhadap Dampak Positif BDR

Adapun kemungkinan dampak negatif proses belajar dari rumah menurut tanggapan guru, yaitu : 75\% guru merasa bahwa mereka mengeluarkan waktu dan tenaga lebih banyak dalam menyiapkan proses pembelajaran, $65 \%$ guru mengeluarkan uang lebih banyak untuk membeli pulsa dan kuota internet dalam menyiapkan pembelajaran, $45 \%$ guru kesulitan mengatur beban pekerjaan di sekolah dan tugas rumah tangga, $85 \%$ guru mengalami kesulitan untuk membuat anak memahami materi, $80 \%$ guru mengalami kesulitan untuk memberikan tanggapan atau umpan balik terhadap hasil kerja siswa, 70\% guru mengalami kesulitan 
untuk memberikan materi atau tugas sesuai dengan kemampuan siswa dan $70 \%$ guru mengalami kesulitan untuk bekerjasama dan berkolaborasi dengan guru lain. Adapun gambaran umum dampak negatif proses belajar dari rumah menurut guru disajikan dalam Gambar Grafik 2 berikut ini.

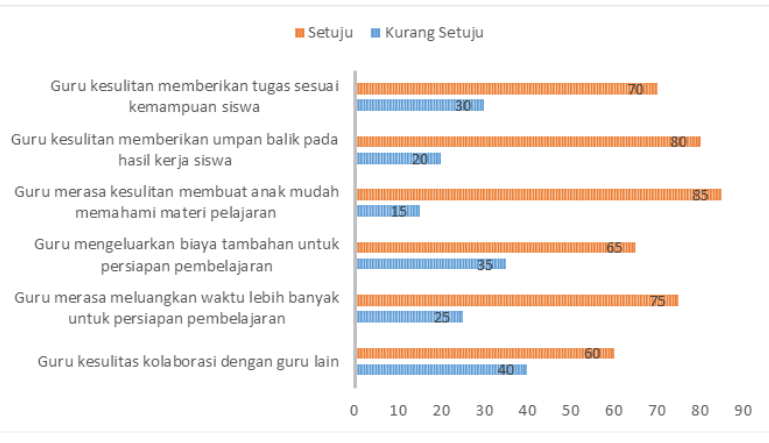

Gambar 3. Grafik Persepsi Guru terhadap Dampak Negatif BDR

\section{PEMBAHASAN}

Merujuk data-data hasil penelitian seperti diuraikan sebelumnya, dapat diketahui bahwa dalam penelitian ini tergambar bagaimana persepsi guru terhadap implementasi kebijakan Belajar dari Rumah (BDR). Kebijakan ini tidak serta merta dengan mudah diterima oleh guru-guru, kepala sekolah, siswa, orang tua siswa dan juga Dinas Pendidikan, yang sudah sangat terbiasa dengan pola pembelajaran tatap muka selama ini. Kondisi ini disinyalir kuat disebabkan oleh ketidaksiapan berbagai pihak dalam menjalankan peran masing-masing secara efektif. Misalnya saja, tentang kesiapan orang tua yang diharapkan untuk mengambil peran lebih dalam menggantikan guru membimbing anak-anak mereka belajar di rumah banyak yang tidak siap, atau bahkan kurang peduli. Dinas pendidikan yang harusnya melakukan pembinaan dan pendampingan kepada sekolah-sekolah juga tidak bisa berbuat banyak, sehingga guru-guru kebingungan bangaimana harus mengajar murid dengan efektif tanpa bertatap muka dengan murid-muridnya. Guru-guru akhirnya dengan inisiatif sendiri melaksanakan proses belajar dari rumah berdasarkan refrensi yang di dapat dari internet dan sumber belajar lainnya.

Sebagian besar guru menyatakan bahwa proses belajar dari rumah belum terlaksana dengan baik, yang di dukung oleh hasil pengamatan guru yang menyatakan bahwa siswa yang benar-benar melaksanakan belajar dari rumah kurang dari setengahnya dari jumlah siswa yang ada. Belum terlaksananya secara efektif proses belajar dari rumah diasumsikan terjadi karena beberapa hal diantaranya adalah dipengaruhi oleh masih terbatasnya kemampuan guru dan siswa untuk melaksanakan proses pembelajaran jarak jauh. Guru dan siswa juga dihadapkan pada sebuah situasi harus siap menghadapi pembelajaran yang biasanya dilaksanakan secara tatap muka berubah menjadi sistem belajar secara daring. Situasi ini tentu saja bukan perkara mudah, karena prosesnya harus mempersiapkan banyak hal agar dapat berjalan secara efektif.

Dalam kondisi ideal, proses pembelajaran dari rumah melalui Pembelajaran Jarak Jauh (PJJ) sejatinya dapat mengakomodasi kebutuhan belajar siswa untuk mengembangkan bakat dan minat sesuai dengan jenjang pendidikannya. Secara konseptual hal tersebut dapat terwujud apabila di dukung oleh kesiapan pendidik, kurikulum yang sesuai, ketersediaan sumber belajar, serta dukungan peranti dan jaringan yang stabil sehingga komunikasi antar peserta didik dan pendidik dapat efektif. Arifa (2020) menyebutkan bahwa kondisi PJJ saat ini belum dapat disebut ideal sebab masih terdapat berbagai hambatan yang dihadapi. Hambatan tersebut sekaligus menjadi tantangan dalam pelaksanaan PJJ mengingat pelaksanaan PJJ merupakan keharusan agar kegiatan pendidikan tetap 
dapat terselenggara di tengah darurat pandemi Covid-19 yang terjadi saat ini.

Dalam hal kesungguhan melaksanakan proses belajar dari rumah, guru-guru SD di Kabupaten Lombok Utara menunjukkan semangat yang baik untuk meningkatkan kemampuannya, hal ini tergambar dari hasil analisa data yang menunjukkan bahwa sebagian besar guru atau sebanyak $65 \%$ orang guru menyatakan bahwa mereka membutuhkan keterampilan tambahan untuk dapat melaksanakan proses belajar dari rumah, keterampilan tersebut didapatkan secara mandiri melalui penelusuran di internet dan bertanya kepada teman sejawat. Kondisi ini sekaligus juga mengindikasikan bahwa kemampuan guru dalam hal mengelola pembelajaran jarak jauh atau kemampuan dalam hal melaksanakan proses BDR masih terbatas.

Hasil penelitian ini relevan dengan hasil studi yang dilakukan oleh beberapa lembaga, baik lembaga pemerintah maupun lembaga swasta non provit lainnya yang menemukan bahwa kebijakan belajar dari rumah masih menemukan banyak tantangan. Misalnya saja dalam sudut padang orang tua siswa, Komisi Perlindungan Anak Indonesia (KPAI) dalam sebuah laporan menyebutkan bahwa KPAI mendapat begitu banyak pengaduan dari orang tua siswa pasca diberlakukannya kebijakan belajar dari rumah oleh pemerintah. Berdasarkan pengaduan tersebut, KPAI kemudian melakukan survey kepada 1.700 siswa di 20 provinsi dan 54 kabupaten/kota di Indonesia. Salah satu hasil survey tersebut menunjukkan bahwa sebanyak 76,7 persen siswa merasa tidak senang belajar dari rumah (Kumparan, 2020).

Studi yang dilakukan oleh Inovasi untuk Anak Sekolah Indonesia (INOVASI) juga menunjukkan hasil yang tidak jauh berbeda. Hasil survey pada sekitar 300 orang tua siswa sekolah dasar di 18 kabupaten dan kota di provinsi Nusa Tenggara Timur (NTT), Nusa Tenggara Barat (NTB), Kalimantan Utara (Kaltara), dan Jawa Timur yang dilakukan pada awal April 2020 menunjukkan bahwa penggunaan media belajar offline pada proses belajar dari rumah lebih dominan daripada penggunaan media online. Untuk NTB saja diketahui pembelajaran online kurang dari $10 \%$. Hasil survey ini juga menemukan adanya ketimpangan akses media pembelajaran yang semakin dalam antara anak-anak dari keluarga ekonomi mampu dan kurang mampu. Anakanak dari kelompok rentan juga diketahui lebih banyak yang tidak belajar dibandingkan anakanak yang berasal dari keluarga ekonomi mampu (Inovasi, 2020).

Hasil studi ini juga sejalan dengan temuantemuan studi cepat BDR dan studi kesiapan daerah menyambut tahun ajaran baru yang dilakukan oleh beberapa pihak belakangan ini. Dari berbagai hasil survey dan wawancara dapat ditegaskan bahwa dalam konteks mengoptimalkan pelaksanaan proses pembelajaran BDR diperlukan dukungan pengembangan kapasitas teknis bagi guru-guru tentang desain dan pengembangan materi yang lebih kontekstual, metode pembelajaran yang sesuai, dan penggunaan teknologi pendukung pembelajaran berbasis internet. Manajemen sekolah harus dapat menjamin keberlangsungan proses tersebut dan dipastikan mendapat dukungan dari kepala sekolah atau pengambil kebijakan di atasnya. Kondisi ini sekaligus memunculkan kesadaran tentang perlunya peningkatan kapabilitas semua pihak, terutama guru-guru dan kepala sekolah, dalam menyampaikan dan mendukung proses belajar dari rumah. Kondisi ini juga menjadi pelajaran penting bagi semua pihak, bahwa peran guru selalu menjadi kunci 
dan ujung tombak setiap kebijakan pendidikan yang diterapkan pemerintah.

Sudah menjadi pengetahuan umum bahwa dalam proses pembelajaran guru tidak hanya berperan sebagai model atau teladan bagi siswanya, akan tetapi juga sebagai pengelola pembelajaran (manager of learning). Dengan demikian, efektivitas proses pembelajaran terletak di pundak guru. Oleh karenanya, keberhasilan suatu proses pembelajaran sangat ditentukan oleh kualitas atau kemapuan guru (Sanjaya, 2008). Dengan demikian, maka penting kemudian memahami bagaimana persepsi guru saat ini mengenai kebijakan belajar dari rumah, dengan mengetahui persepsi guru saat ini, maka dapat diprediksi guru akan bertindak seperti apa dalam proses pembelajaran, karena seperti disebutkan sebelumnya bahwa tindakan dimulai dari persepsi. Persepsi guru yang berkembang saat ini terkait proses BDR yang dihimpun dari berbagai studi sekali lagi mengindikasikan bahwa perlu ada upaya peningkatan kapasitas guru di masa pandemi bila ingin kebijakan BDR berjalan sesuai harapan.

\section{SIMPULAN}

COVID-19 adalah penyakit baru yang telah menjadi pandemi. Penyakit ini harus diwaspadai karena penularan yang relatif cepat, memiliki tingkat mortalitas yang tidak dapat diabaikan, dan belum adanya terapi definitive (Susilo, 2020). Atas dasar itulah kemudian pemerintah Republik Indonesia melalui Kementerian Pendidikan dan Kebudayaan menerapkan kebijakan belajar dari rumah sebagai upaya mencegah penularan wabah Covid-19. Dalam praktiknya, penerapan proses belajar dari rumah mendapat respon yang beragam dari guru yang dipengaruhi oleh beragamnya persepsi guru mengenai proses belajar dari rumah.
Mengingat bahwa sebuah tindakan dipengaruhi oleh persepsi, maka tentu menjadi penting untuk mengetahui bagaimana sesungguhnya persepsi guru terhadap kebijakan belajar dari rumah. Hasil penelitian ini menyimpulkan bahwa kebijakan belajar dari rumah selama masa pandemic Covid-19 menurut persepsi guru belum terlaksana dengan baik dan menurut pengamatan guru, hanya $25 \%$ siswa saja yang benar-benar melaksanakan belajar dari rumah. Sebanyak $60 \%$ guru merasa bahwa beban mereka menjadi lebih berat bila dibandingkan dengan proses belajar yang selama ini dilakukan secara klasikan maupun tatap muka dan $65 \%$ guru menyatakan bahwa mereka membutuhkan keterampilan tambahan untuk dapat melaksanakan proses belajar dari rumah.

Gambaran persepsi guru ini dapat dijadikan rujukan atau pertimbangan dalam memberikan treatment untuk meningkatkan kompetensi guru dalam mengelola proses belajar dari rumah. Harus diakui bahwa kegiatan belajar dari rumah bukan merupakan konsep pendidikan yang umum dilakukan, sehingga wajar kemudian menimbulkan persepsi yang beragam, kebijakan ini juga terkesan dilakukan dengan persiapan seadanya bahkan nyaris tanpa persiapan, sehingga masih banyak dijumpai kesenjangan dalam implementasinya, oleh karena itu disarankan kepada peneliti-peneliti lain untuk melalukan studi-studi lebih lanjut mengenai bidang ini.

\section{DAFTAR PUSTAKA}

Alam, Syamsir (2020). Belajar di Masa Pandemi. Online https://mediaindonesia.com /read/detail/298260-belajar-di-masapandemi 
Arifa, Fieka Nurul (2020). Tantangan Pelaksanaan Kebijakan Belajar Dari Rumah dalam Masa Darurat Covid19. Pusat Penelitian Badan Keahlian DPR RI : Kajian Singkat Terhadap Isu Aktual dan Strategis. Vol. XII, No. 7 hal : $13-18$.

Dewi, Wahyu Aji Fatma, (2020). Dampak Covid-19 Terhadap Implementasi Pembelajaran Daring di Sekolah Dasar. Edukatif : Jurnal Ilmu Pendidikan. Volume 2 Nomor 1 April 2020, ISSN Online : 2656-80715561.

Guetterman, T. C. (2015). Descriptions of Sampling Practices within Five Approaches to Qualitative Research in Education and the Health Sciences.

Inovasi, (2020). Riset dampak COVID-19: Potret gap akses online 'Belajar dari Rumah' dari 4 provinsi. [Online] https://theconversation.com/risetdampak-covid-19-potret-gap-aksesonline-belajar-dari-rumah-dari-4provinsi-136534

Kumparan, (2020). Survei KPAI: 76,7\% Siswa Tidak Senang Belajar dari Rumah. [Online]

https://kumparan.com/kumparanmo m/survei-kpai-76-7-siswa-tidaksenang-belajar-dari-rumah$\underline{1 \mathrm{tJ} 084 \mathrm{bBo} 3 \mathrm{k} / \mathrm{full}}$

Menteri Pendidikan dan Kebudayaan. (2020). Surat Edaran Nomor 3 Tahun 2020 Tentang Pelaksanaan Pendidikan dalam Masa Darurat Corona Virus (COVID-19).
Morissan. (2017). Metode Penelitian Survei. Jakarta: Kencana

Purwanto, Agus, dkk (2020). Studi Eksploratif Dampak Pandemi COVID-19 Terhadap Proses Pembelajaran Online di Sekolah Dasar. Edu PsyCouns Journal. Journal of Education, Psychology and Counseling. Volume 2 Nomor 1 (2020) ISSN Online : 2716-4446, 1 12

Sanjaya, Wina, (2008), Kurikulum dan Pembelajaran : Teori dan Praktik Pengembangan Kurikulum Tingkat Satuan Pendidikan (KTSP), Jakarta: Kencana.

Sarwono, Sarlito W. (2009). Pengantar Psikologi Umum. Depok: Rajawali Pers.

Susilo, Adityo, dkk. (2020). Coronavirus Disease 2019: Tinjauan Literatur Terkini Coronavirus Disease 2019: Review of Current Literatures. Jurnal Penyakit Dalam Indonesia | Vol. 7, No. 1 Hal : 45 - 67.

World Health Organization. (2020) WHO Director-General's opening remarks at the media briefing on COVID-19 11 March 2020. World Health Organization. [online] 